\title{
Early diagnosis and treatment of breast cancer in Japanese kidney transplant recipients: a single center experience
}

\author{
Taigo Kato ${ }^{1}$, Yoichi Kakuta ${ }^{1 *}$, Kazuaki Yamanaka ${ }^{1}$, Masayoshi Okumi ${ }^{2}$, Toyofumi Abe ${ }^{1}$, Ryoichi Imamura ${ }^{1}$, \\ Naotsugu Ichimaru ${ }^{3}$, Shiro Takahara ${ }^{3}$ and Norio Nonomura ${ }^{1}$
}

\begin{abstract}
Background: The incidence of malignancies in kidney transplant recipients is increasing. Breast cancer is a common malignancy after kidney transplantation and can be more aggressive in kidney transplant recipients than in the general population. In this study, we evaluated the incidence and prognosis of breast cancer in kidney transplant recipients.

Findings: Between 1993 and 2013, 750 kidney transplant patients were followed-up at our center. Since 1999, annual physical examination, mammography, and breast ultrasonography have been performed for such patients. Diagnostic studies, including core needle or mammotome biopsy, were performed for suspected malignancies. Patients with malignant neoplasm were administered the appropriate treatment and followed-up to assess tumor response and symptoms.

Nine patients were diagnosed with breast cancer during the follow-up period. The mean age at the initial detection of the breast cancer was $47.7 \pm 8.4$ years. The mean interval from transplantation to diagnosis was $148.7 \pm 37.1$ months. Of the 9 patients, 8 were detected through the screening test; 7 were treated with breast conservative surgery and 1 was treated with modified radical mastectomy. The cancer stages were $0(n=2), I(n=6)$, and II $(n=1)$. The incidence of breast cancer tended to be unchanged with time between transplantation and diagnosis, inconsistent with the increase in the duration of immunosuppression.
\end{abstract}

Conclusion: Annual screening tests are crucial in the early diagnosis of breast cancer. Early treatment of breast cancer can result in an excellent prognosis in kidney transplant recipients.

Keywords: Breast cancer; Kidney transplantation; Prognosis; Screening

\section{Introduction}

Advances in the development of immunosuppressive agents have significantly reduced the acute rejection rate and markedly improved graft survival in kidney transplantation (Meier-Kriesche et al. 2004). Despite these encouraging trends, the long-term patient survival rate after kidney transplantation has remained unchanged (Webster et al. 2008; Campistol 2009). The high mortality among kidney transplant recipients (KTRs) is attributed mainly to cardiovascular disease and malignancy

\footnotetext{
* Correspondence: kakuta@uro.med.osaka-u.ac.jp

${ }^{1}$ Department of Urology, Osaka University Graduate School of Medicine, 2-2 E4 Yamadaoka, Suita, Osaka 565-0871, Japan

Full list of author information is available at the end of the article
}

(Campistol 2009). Over the next decade, the mortality rate from malignancy among transplant recipients will exceed that from cardiovascular disease (Buell et al. 2005). In Europe and North America, the chronic use of immunosuppressants is associated with an increasing rate of malignancy after kidney transplantation (Grulich et al. 2007; Engels et al. 2011; Van Leeuwen et al. 2010). Although the greatest relative increase was observed in the risks of non-melanoma skin cancers and cancers associated with viral infection, the risk of more common solid organ cancers also significantly increased among patients with a relative risk compared with the general population (Webster et al. 2008; Kasiske et al. 2004; Vajdic et al. 2006).

\section{至}

(C) 2015 Kato et al.; licensee Springer. This is an Open Access article distributed under the terms of the Creative Commons Attribution License (http://creativecommons.org/licenses/by/4.0), which permits unrestricted use, distribution, and reproduction in any medium, provided the original work is properly credited. 
KTRs who develop breast cancer (BC) are often younger at diagnosis and have poorer outcomes than the general population (Buell et al. 2002). BC is the most common cancer and the leading cause of cancer-related death worldwide. Major risk factors include age, family history, and long-term hormonal replacement therapy, which have been strongly linked to cancer stage at diagnosis (Ferlay et al. 2010). In Japanese women between the ages of 40 and 59 years, BC is the leading cause of death, which is considered a growing social problem (Matsuda et al. 2013). However, relatively few studies have addressed the occurrence of BC in KTRs. It remains controversial whether screening tests can reduce $\mathrm{BC}$ development after kidney transplantation. In this study, although the number of cases was limited, we aimed to evaluate the efficacy of conducting screening tests for BC in KTRs.

\section{Patients and methods Subjects}

Between 1993 and 2013, 750 kidney transplant patients underwent routine follow-up with or without screening at our kidney transplant center. All the clinical data of the KTRs were obtained from our department database. Among the patients, 77 developed de novo malignancy (6 with double cancers) and 9 were diagnosed with BC. Patient characteristics are shown in Table 1. All the patients were closely monitored by performing screening tests. In particular, all the female patients were followedup annually from 1999 through physical examination, mammography (MMG), and breast ultrasonography (USG). Diagnostic evaluations, including a core needle or mammotome biopsy, were performed for suspected malignancies. Patients with a malignant neoplasm were administered the appropriate treatment and followed-up to assess tumor response and symptoms. All the $\mathrm{BC}$ patients were women who underwent surgery between 1998 and 2013.

The study protocol was approved by the Institutional Review Board of Osaka University Hospital (approval no. 14150).

Table 1 Baseline characteristics of kidney transplant recipients

\begin{tabular}{lll}
\hline & Total Recipients & BC \\
\hline Total number & 750 & 9 \\
Age at transplant & $38.6 \pm 13.3$ & $47.7 \pm 2.8$ \\
Gender (M/F) & $454 / 296$ & $0 / 9$ \\
Duration to diagnosis (months) & & $148.7 \pm 37.1$ \\
Duration of dialysis (years) & $3.7 \pm 0.2$ & $4.9 \pm 0.9$ \\
Donor type (Living/Cadaveric) & $557 / 193$ & $7 / 2$ \\
Duration of follow-up (years) & $8.8 \pm 2.4$ & $6.7 \pm 4.9$ \\
\hline
\end{tabular}

BC: Breast cancer.

\section{Statistical analysis}

Kaplan-Meier estimates were used to calculate patient and graft survival rates. The primary end-point was death (overall survival [OS]). OS was defined as the time from diagnosis of $\mathrm{BC}$ to death. Statistical significance was determined using the chi-square test. Differences were considered statistically significant at $p<0.05$.

\section{Results}

\section{Malignancy}

The overall incidence of malignancy, including multiple primary malignancy, during the follow-up period was $10.3 \%$ (77/750 patients). The mean recipient age was $43.6 \pm 12.8$ years, with $31.4 \%$ of the patients aged $>50$ years. The mean interval from transplantation to diagnosis was $134.5 \pm 11.3$ months. Other characteristics of the patients are described in Table 1.

\section{Incidence of BC}

BC was diagnosed in 9 female recipients $(11.7 \%$ of all malignancy cases) but in none of the male recipients. The mean age at the initial detection of $\mathrm{BC}$ was $47.7 \pm$ 8.4 years. The mean interval from the time of transplantation to diagnosis was $148.7 \pm 37.1$ months.

The demographic characteristics of the KTRs with BC are described in Table 2. In 8 of the 9 patients, $\mathrm{BC}$ was detected using a screening test. The $\mathrm{BC}$ patients underwent breast-conserving surgery $(n=7)$ or modified radical mastectomy $(\mathrm{n}=2)$. The cancer stages were 0 $(\mathrm{n}=2)$, I $(\mathrm{n}=6)$, and II $(\mathrm{n}=1)$. Four patients received adjuvant endocrine therapy depending on their hormone receptor-positive status. None of the patients received adjuvant chemotherapy. Seven patients received therapy with mycophenolate mofetil and calcineurin inhibitors (CNIs) immediately after kidney transplantation. Of the 9 patients, 2 were administered azathioprine as an antimetabolite. Since 2004, 3 patients have received induction therapy with anti-CD25 antibodies. None of the patients experienced acute rejection episodes. Adjustment of immunosuppressants was not required after BC diagnosis.

Eight patients were asymptomatic at the time of $\mathrm{BC}$ diagnosis, which was detected during the routine screening test. Before the screening system was introduced in 1999, 1 patient felt her own breast mass in 1998. The cancer stages were $0(n=2), I(n=5)$, and II $(n=1)$ in the patients diagnosed through the screening test. The patients diagnosed by using the screening test were treated with breast-conservative surgeries $(n=7)$ or modified radical mastectomy $(\mathrm{n}=1)$.

The incidence of $\mathrm{BC}$ remained unchanged with time between transplantation and diagnosis, which did not coincide with the increase in the duration of immunosuppressant treatment (Figure 1). After transplantation, 
Table 2 Characteristics of breast cancers in kidney transplant recipients

\begin{tabular}{|c|c|c|c|c|c|c|c|c|c|c|c|c|}
\hline Patients & Age & $\begin{array}{l}\text { Duration to } \\
\text { diagnosis } \\
\text { (months) }\end{array}$ & $\begin{array}{l}\text { screening } \\
\text { test }\end{array}$ & $\begin{array}{l}\text { MMG } \\
\text { positive }\end{array}$ & $\begin{array}{l}\text { USG } \\
\text { positve }\end{array}$ & Procedure & Pathology & Stage & $\begin{array}{l}\text { Positivity of } \\
\text { hormone } \\
\text { receptor }\end{array}$ & Recurrence & Status & $\begin{array}{l}\text { Follow-up } \\
\text { duration }\end{array}$ \\
\hline 1 & 59 & 343 & + & + & + & CS & $\begin{array}{l}\text { solid-tubular } \\
\text { carcinoma }\end{array}$ & 1 & $\begin{array}{l}\text { ER(-),PR(-), } \\
\operatorname{HE2}(+)\end{array}$ & - & Alive & 79 \\
\hline 2 & 56 & 262 & + & + & + & CS & $\begin{array}{l}\text { solid-tubular } \\
\text { carcinoma }\end{array}$ & 1 & N/A & - & Dead & 56 \\
\hline 3 & 58 & 270 & + & + & + & CS & $\begin{array}{l}\text { non invasive } \\
\text { ductal } \\
\text { carcinoma }\end{array}$ & 0 & $\begin{array}{l}\text { ER(-),PR(-), } \\
\operatorname{HE2}(+)\end{array}$ & - & Alive & 69 \\
\hline 4 & 46 & 66 & - & - & - & MRM & $\begin{array}{l}\text { solid-tubular } \\
\text { carcinoma }\end{array}$ & 1 & $\mathrm{ER}(-)$ & - & Alive & 187 \\
\hline 5 & 42 & 57 & + & + & + & CS & $\begin{array}{l}\text { papillotubular } \\
\text { carcinoma }\end{array}$ & 1 & $\mathrm{HE} 2(+)$ & - & Alive & 142 \\
\hline 6 & 48 & 48 & + & - & + & CS & $\begin{array}{l}\text { papillotubular } \\
\text { carcinoma }\end{array}$ & 1 & $\begin{array}{l}\mathrm{ER}(+), \operatorname{PR}(-), \\
\mathrm{HE2}(-)\end{array}$ & - & Alive & 113 \\
\hline 7 & 41 & 113 & + & + & + & CS & $\begin{array}{l}\text { solid-tubular } \\
\text { carcinoma }\end{array}$ & 1 & $\begin{array}{l}\operatorname{ER}(+), \operatorname{PR}(-), \\
\operatorname{HE} 2(+)\end{array}$ & - & Alive & 24 \\
\hline 8 & 35 & 80 & + & - & + & CS & $\begin{array}{l}\text { papillotubular } \\
\text { carcinoma }\end{array}$ & 0 & $\begin{array}{l}\mathrm{ER}(+), \mathrm{PR}(+), \\
\operatorname{HE2}(+)\end{array}$ & - & Alive & 43 \\
\hline 9 & 44 & 99 & + & + & + & MRM & $\begin{array}{l}\text { non invasive } \\
\text { ductal } \\
\text { carcinoma }\end{array}$ & $2 \mathrm{~A}$ & $\begin{array}{l}\mathrm{ER}(+), \operatorname{PR}(+), \\
\operatorname{HE2}(+)\end{array}$ & - & Alive & 5 \\
\hline
\end{tabular}

MGM: Mammography, USG: Ultrasonography.

CS: Conservative surgery, MRM: Modified radical mastectomy.

ER: Estrogen receptor, PR: Progesteron receptor, HER2: Human EFGR related-2.

BC developed in 2 patients $(1.1 \%)$ in $<5$ years, in 4 patients (2.2\%) between 5 and 9 years, and in 3 patients $(0.8 \%)$ at $>9$ years. The 5 -year survival rate was $100 \%$ for stage 0 , $97.7 \%$ for stage I, and $100 \%$ for stage II, with no tumor recurrence. After a median follow-up period of 56 months, 1 patient with double cancer died of uterine cancer.

\section{Discussion}

The incidence of cancer after kidney transplantation has increased in recent years due to the increase in patient survival (Meier-Kriesche et al. 2004; Webster et al. 2008;
Campistol 2009; Grulich et al. 2007). Cancers in KTRs usually have a more aggressive feature, with rapid progression. The most common cancers in KTRs were non-melanoma skin cancer, urological cancer, and lymphoproliferative disease (Meier-Kriesche et al. 2004; Webster et al. 2008; Campistol 2009; Grulich et al. 2007; Vajdic et al. 2006).

Only few studies have evaluated the incidence of BC post-renal transplantation, although several other cancers have been known to occur more frequently after transplantation (Kasiske et al. 2004; Birkeland et al. 2000; Pedotti et al. 2003; Kauffman et al. 2006). KTRs seemed to

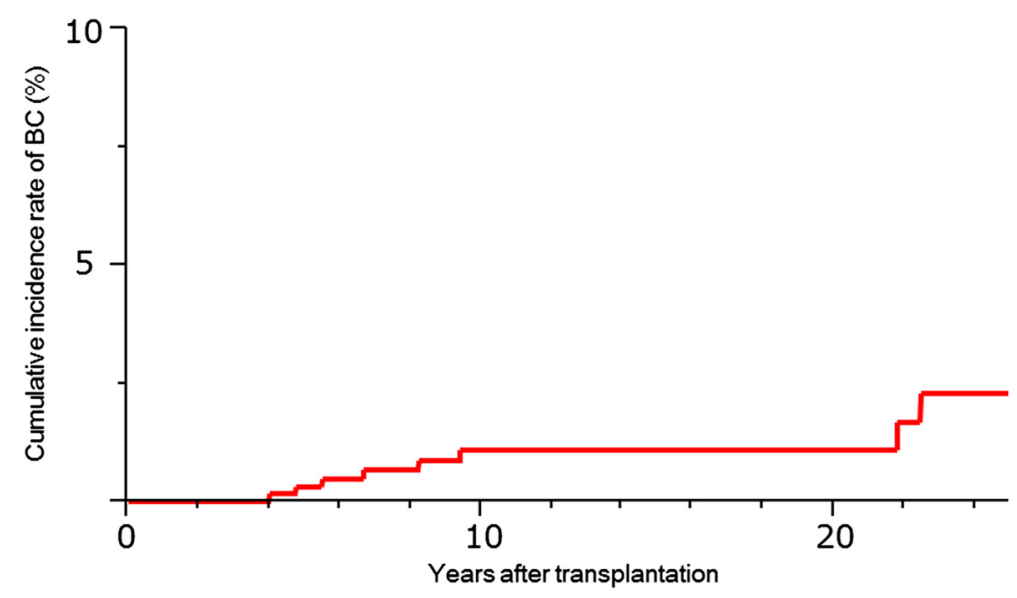

Figure 1 Cumulative incidence rate of breast cancer $(\mathrm{BC})$ after kidney transplantation. 
have a slightly lower risk of $\mathrm{BC}$ than the general population (Agraharkar et al. 2004; Stewart et al. 1995). This could be attributed to the intensive medical screening performed before transplantation, resulting in the exclusion of highrisk patients. Meanwhile, KTRs had undergone long-term dialysis therapy before kidney transplantation. Therefore, given that KTRs require immunosuppressants throughout life, it is necessary to consider the incidence of cancer in dialysis patients as a control group. Vajvic et al. compared the incidence of cancer in KTRs with that in dialysis patients on the waiting list for transplantation. According to the study, kidney transplantation did not increase the risk of other types of cancer including BC although the risk of skin cancer, Kaposi's sarcoma and malignant lymphoma is increased more than twice in KTRs.

However, Buell et al. also reported that while immunosuppression may not increase the incidence of $\mathrm{BC}$, it might increase the biological aggressiveness of $\mathrm{BC}$ (Buell et al. 2002). These reports suggest that early detection of $\mathrm{BC}$ may be important for the diagnosis of the disease at an early stage and for initiating the appropriate therapy. In the present study, the incidence of $\mathrm{BC}$ among the KTRs was found to be $1.2 \%$ at a mean of 148.7 months after transplantation. This rate is higher than that previously reported owing to our strict screening system, which permitted the earlier detection of $\mathrm{BC}$ in our study than in previous studies (Buell et al. 2002; Kwak et al. 2013; Popov et al. 2007). It is particularly worth noting that 8 of $9 \mathrm{BC}$ were detected after the screening system was initiated in 1999. Among 8 screening-detected patients, 7 were treated with conservative surgery. One patient who was monitored through screening tests for 8 years underwent bilateral modified radical mastectomy. In this case, the histology was noninvasive ductal carcinoma, which is difficult to detect during screening.

The incidence of $\mathrm{BC}$ was unchanged despite the time that lapsed after transplantation in the present study, which is consistent with the previous reports (Buell et al. 2002; Agraharkar et al. 2004; Kwak et al. 2013). This finding suggests that KTRs should continue to undergo long-term screening after transplantation to improve patient outcomes. Generally, the morbidity of BC in Japan is reported to be 103.6 per 100000 which is the most common number in female population and Japanese breast cancer society recommends that women over 40 years should receive $\mathrm{BC}$ screening. In the guidelines for the management of transplant recipients, the screening test for BC is recommended for KTRs aged between 50 and 70 years (Kasiske et al. 2000; EBPG Expert Group on Renal Transplantation 2002). However, considering that the mean age at initial detection of $\mathrm{BC}$ in our study was 47.7 years, we recommend that patients aged between 40 and 50 years should also undergo the screening test in the same manner as general population.
The benefits of MMG in the detection of BC have long been established (Humphrey et al. 2002). However, MMG has a serious limitation in that its rate of falsenegative results can be as high as $35 \%$, especially in women with dense breast tissue (Majid et al. 2003). Moreover, most Japanese women have dense or heterogeneously dense breast on MMG compared to Western women (Takamoto et al. 2013). This can lead to the possibility of missing a cancer lesion. At our center, we also conduct breast USG to compensate for the weakness of MMG and increase the discovery rate of early BC. Interestingly, in some patients, USG clearly showed an irregular and heterogenous nodule though no dominant mass was detected in MMG. In Japan, a large clinical study of adjunct USG is ongoing to address the issue of BC mortality rate reduction (Ishida et al. 2014).

Management of patients by using immunosuppressant drugs after $\mathrm{BC}$ diagnosis is a matter of concern. The therapeutic benefit of reducing the dose of immunosuppressant drugs in patients with solid organ tumors is controversial (Self et al. 2006). In some studies, CNI use was not a risk factor of any type of malignancy (Marcen et al. 2003). Moreover, the overall amount of immunosuppressant may not lead to an increased incidence of BC (Buell et al. 2002). These findings suggest that decreasing the dose or discontinuation of immunosuppressants may be unnecessary for the KTRs with BC after diagnosis. In our cases, the dose of immunosuppresants remained unchanged after $\mathrm{BC}$ diagnosis.

Renal graft function should be considered before chemotherapy, as some chemotherapeutic agents can affect graft function. Paclitaxel might be an appropriate option for patients with impaired graft function. Data regarding hormonal therapy in these patients are limited.

Recent studies suggest that the use of mammalian targets of rapamycin inhibitors (e.g., sirolimus and everolimus) may reduce the overall risk of solid organ tumors after kidney transplantation (Alberu et al. 2011; Piselli et al. 2013). Furthermore, recent clinical trials reported positive effects of everolimus in improving progressionfree survival in women with BC (Baselga et al. 2012). In our center, since 2010, patients with stable renal function who are receiving CNI have been converted to everolimus. The potential protective effect would result in a reduced incidence of BC after kidney transplantation.

Some limitations should be considered when interpreting our results. First, despite our sample size, we had a limited number of $\mathrm{BC}$ cases $(\mathrm{n}=9)$ in the KTRs population. Second, the median follow-up period for the KTRs with $\mathrm{BC}$ was inadequate. Finally, this was a retrospective study; therefore, we could not control for all confounding variables. However, it is notable that this is the first study to evaluate the incidence of $\mathrm{BC}$ in Japanese KTRs. 
In summary, given an appropriate screening program, KTRs with $\mathrm{BC}$ can be successfully treated using a minimally invasive modality. Although our sample size was small, our experience shows that the patient prognosis in $\mathrm{BC}$ is excellent if treatment is administered during the initial stages. We highly recommend $\mathrm{BC}$ screening for KTRs to facilitate early detection of BC.

\section{Consent}

Written informed consent was obtained from the patient for the publication of this report and any accompanying images.

\section{Competing interests}

The authors declare that they have no competing interests.

\section{Authors' contributions}

TK designed the study, performed data analysis, and drafted the article. YK provided the study design and the working hypothesis and completed the article. $\mathrm{KY}, \mathrm{MO}, \mathrm{TA}, \mathrm{Rl}$, and NI provided scientific advice. ST and NN provided guidance throughout the study. All authors read and approved the final manuscript.

\section{Acknowledgments}

The authors thank Youko Watanabe and Dr. Yukito Kokado for conducting the clinical data collection.

\section{Author details}

'Department of Urology, Osaka University Graduate School of Medicine, 2-2 E4 Yamadaoka, Suita, Osaka 565-0871, Japan. ${ }^{2}$ Department of Urology, Tokyo Women's Medical University Graduate School of Medicine, 8-1 Kawada-cho, Shinjyuku-ku, Tokyo 162-8666, Japan. ${ }^{3}$ Department of Advanced Technology for Transplantation, Osaka University Graduate School of Medicine, 2-2 Yamadaoka, Suita, Osaka 565-0871, Japan.

Received: 20 January 2015 Accepted: 25 March 2015

Published online: 25 April 2015

\section{References}

Agraharkar ML, Cinclair RD, Kuo YF, Daller JA, Shahinian VB (2004) Risk of malignancy with long-term immunosuppression in renal transplant recipients. Kidney Int 66:383-389

Alberu J, Pascoe MD, Campistol JM, Schena FP, Rial Mdel C, Polinsky M, Neylan JF, Korth-Bradley J, Goldberg-Alberts R, Maller ES, Sirolimus CONVERT Trial Study Group (2011) Lower malignancy rates in renal allograft recipients converted to sirolimus-based, calcineurin inhibitor-free immunotherapy: 24-month results from the CONVERT trial. Transplantation 92:303-310

Baselga J, Campone M, Piccart M, Burris HA 3rd, Rugo HS, Sahmoud T, Noguchi S, Gnant M, Pritchard Kl, Lebrun F, Beck JT, Ito Y, Yardley D, Deleu I, Perez A, Bachelot T, Vittori L, Xu Z, Mukhopadhyay P, Lebwohl D, Hortobagyi GN (2012) Everolimus in postmenopausal hormone-receptor-positive advanced breast cancer. N Engl J Med 366:520-529

Birkeland SA, Lokkegaard H, Storm HH (2000) Cancer risk in patients on dialysis and after renal transplantation. Lancet 355:1886-1887

Buell JF, Hanaway MJ, Trofe J, Gross TG, Beebe TM, Alloway RR, First MR, Woodle ES (2002) De novo breast cancer in renal transplant recipients. Transplant Proc 34:1778-1779

Buell JF, Gross TG, Woodle ES (2005) Malignancy after transplantation. Transplantation 80:S254-S264

Campistol JM (2009) Minimizing the risk of posttransplant malignancy. Transplantation 87:S19-S22

EBPG Expert Group on Renal Transplantation (2002) European best practice guidelines for renal transplantation. Section IV: Long-term management of the transplant recipient. Nephrol Dial Transplant 17(4):1-67

Engels EA, Pfeiffer RM, Fraumeni JF Jr, Kasiske BL, Israni AK, Snyder JJ, Wolfe RA, Goodrich NP, Bayakly AR, Clarke CA, Copeland G, Finch JL, Fleissner ML, Goodman MT, Kahn A, Koch L, Lynch CF, Madeleine MM, Pawlish K, Rao C, Williams MA, Castenson D, Curry M, Parsons R, Fant G, Lin M (2011) Spectrum of cancer risk among US solid organ transplant recipients. JAMA 306:1891-1901
Ferlay J, Shin HR, Bray F, Forman D, Mathers C, Parkin DM (2010) Estimates of worldwide burden of cancer in 2008: GLOBOCAN 2008. Int J Cancer 127:2893-2917

Grulich AE, Van Leeuwen MT, Falster MO, Vajdic CM (2007) Incidence of cancers in people with HIV/AIDS compared with immunosuppressed transplant recipients: a meta-analysis. Lancet 370:59-67

Humphrey LL, Helfand M, Chan BK, Woolf SH (2002) Breast cancer screening: a summary of the evidence for the U.S. Preventive Services Task Force. Ann Intern Med 137:347-360

Ishida T, Suzuki A, Kawai M, Narikawa Y, Saito H, Yamamoto S, Tohno E, Sobue T, Fukuda M, Ohuchi N (2014) A Randomized controlled trial to verify the efficacy of the use of ultrasonography in breast cancer screening aged 40-49 (J-START): 76196 women registered. Jpn J Clin Oncol 44:134-140

Kasiske BL, Vazquez MA, Harmon WE, Brown RS, Danovitch GM, Gaston RS, Roth D, Scandling JD, Singer GG (2000) Recommendations for the outpatient surveillance of renal transplant recipients. American Society of Transplantation. J Am Soc Nephrol 11(15):S1-S86

Kasiske BL, Snyder JJ, Gilbertson DT, Wang C (2004) Cancer after kidney transplantation in the United States. Am J Transplant 4:905-913

Kauffman HM, Cherikh WS, McBride MA, Cheng Y, Hanto DW (2006) Post-transplant de novo malignancies in renal transplant recipients: the past and present. Transpl Int 19:607-620

Kwak HY, Chae BJ, Bae JS, Jung SS, Song BJ (2013) Breast cancer after kidney transplantation: a single institution review. World J Surg Oncol 11:77

Majid AS, De Paredes ES, Doherty RD, Sharma NR, Salvador X (2003) Missed breast carcinoma: pitfalls and pearls. Radiographics 23:881-895

Marcen R, Pascual J, Tato AM, Teruel JL, Villafruela JJ, Fernández M, Tenorio M, Burgos FJ, Ortuño J (2003) Influence of immunosuppression on the prevalence of cancer after kidney transplantation. Transplant Proc 35:1714-1716

Matsuda A, Matsuda T, Shibata A, Katanoda K, Sobue T, Nishimoto H, Japan Cancer Surveillance Research Group (2013) Cancer incidence and incidence rates in Japan in 2007: a study of 21 population-based cancer registries for the Monitoring of Cancer Incidence in Japan (MCIJ) project. Jpn J Clin Oncol 43:328-336

Meier-Kriesche HU, Schold JD, Srinivas TR, Kaplan B (2004) Lack of improvement in renal allograft survival despite a marked decrease in acute rejection rates over the most recent era. Am J Transplant 4:378-383

Pedotti P, Cardillo M, Rossini G, Arcuri V, Boschiero L, Caldara R, Cannella G, Dissegna D, Gotti E, Marchini F, Maresca MC, Montagnino G, Montanaro D, Rigotti P, Sandrini S, Taioli E, Scalamogna M (2003) Incidence of cancer after kidney transplant: results from the North Italy transplant program. Transplantation 76:1448-1451

Piselli P, Serraino D, Segoloni GP, Sandrini S, Piredda GB, Scolari MP, Rigotti P, Busnach G, Messa P, Donati D, Schena FP, Maresca MC, Tisone G, Veroux M, Sparacino V, Pisani F, Citterio F, Immunosuppression and Cancer Study Group (2013) Risk of de novo cancers after transplantation: results from a cohort of 7217 kidney transplant recipients, Italy 1997-2009. Eur J Cancer 49:336-344

Popov Z, Ivanovski O, Kolevski P, Stankov O, Petrovski D, Cakalaroski K, Ivanovski N (2007) De novo malignancies after renal transplantation-a single-center experience in the Balkans. Transplant Proc 39:2589-2591

Self M, Dunn E, Cox J, Brinker K (2006) Managing breast cancer in the renal transplant patient: a unique dilemma. Am Surg 72:150-153

Stewart T, Tsai SC, Grayson H, Henderson R, Opelz G (1995) Incidence of de-novo breast cancer in women chronically immunosuppressed after organ transplantation. Lancet 346:796-798

Takamoto Y, Tsunoda H, Kikuchi M, Hayashi N, Honda S, Koyama T, Ohde S, Yagata H, Yoshida A, Yamauchi H (2013) Role of breast tomosynthesis in diagnosis of breast cancer for Japanese women. Asian Pac J Cancer Prev 14:3037-3040

Vajdic CM, McDonald SP, McCredie MR, van Leeuwen MT, Stewart JH, Law M, Chapman JR, Webster AC, Kaldor JM, Grulich AE (2006) Cancer incidence before and after kidney transplantation. JAMA 296:2823-2831

Van Leeuwen MT, Webster AC, McCredie MR, Stewart JH, McDonald SP, Amin J, Kaldor JM, Chapman JR, Vajdic CM, Grulich AE (2010) Effect of reduced immunosuppression after kidney transplant failure on risk of cancer: population based retrospective cohort study. BMJ 340:C570

Webster AC, Wong G, Craig JC, Chapman JR (2008) Managing cancer risk and decision making after kidney transplantation. Am J Transplant 8:2185-2191 